\title{
A matter of choice-professionals' views on the incorporation of practical work with intimate partner violence into Swedish personal social services
}

\author{
Lisa Lundberg* \\ Department of Social Work \\ Stockholm University \\ Email: lisa.lundberg@socarb.su.se
}

\author{
Hugo Stranz \\ Department of Social Work \\ Stockholm University \\ Email: hugo.stranz@socarb.su.se
}

*corresponding author

\begin{abstract}
During the last decades, efforts have been made to increase local support provided to victims of intimate partner violence (IPV) in Sweden. As with other social problems, responsibility to address IPV falls on the municipal personal social services. The present article draws upon data obtained via structured telephone interviews with designated personal social services staff members from a sample of 99 municipalities, focusing on aspects of potential progress in social work with IPV. The results show that successful incorporation of IPV into personal social services largely seems to depend upon the commitment and dedication of individual actors within the organisations. Furthermore, the data indicate that competence in this field depends on personal inclination, with attention to IPV appearing as 'a matter of choice'. The results are analysed using neo-institutional theory as well as concepts related to social movement studies, with focus on individual agency in organisational change and the potential relevance of IPV as an issue related to gender inequality to gender inequality. The analysis suggests that while IPV social work may challenge institutionalised practises within social services, change may go both ways with IPV being reframed to fit within the established framework of social services.
\end{abstract}


Keywords: Intimate Partner Violence, Domestic Violence, Social Services, Organisational Change

\section{Introduction}

As in many other affluent nations, the Swedish women's shelter movement emerged from the greater radical feminist social movement during the late 1970s. A basic principle of this movement was the idea of women helping other women, not only by providing individual support but also by instigating political change. The movement has been largely successful; men's violence against women has been placed on the agenda of the UN, the EU and national governments (e.g., European Union Agency For Fundamental Rights, 2014; cf. Garcia \& Merlo, 2016). Likewise, in compliance with the Nordic Council of Ministers' $(2005,2017)$ goal to increase gender equality, the Swedish government has made eliminating men's violence against women a central goal.

Over time, by gradually raising awareness of men's violence against women, this social problem has been recognised by Swedish social services. In contrast to the non-government sector, social services are not only bound by a large number of rules and regulations but also demand professionalism and handling of social problems on an individual level (Lehrner \& Allen, 2009; Mehrotra, Kimball, \& Wahab, 2016; Stranz, Wiklund, \& Karlsson, 2016). This implies that, as men's violence against women has been incorporated into social services, the more political aspects of the issue as it was expressed by the feminist social movement have somewhat diminished (see Barrett, Almanssori, Kwan, \& Waddick, 2016; Lehrner \& Allen, 2009).

The Social Services Act (SFS 2001:453), which regulates all municipality-based social work in Sweden, is a framework law that gives municipalities extensive autonomy to organise and carry out services. While such discretion renders it possible to adapt both services and organisations to meet the specific and local needs of individuals, it also leads to variation in how services are carried out (Stranz et al., 2016). Consequently, official reports identify general difficulties and local variations in the incorporation of intimate partner violence (IPV) into social service organisations (National Board of Health and Welfare, 2014; SOU 2004:121; SOU 2015:55). While some organisations have provided specialised support for decades, others have not yet started to develop services focusing on victims of IPV (National Board of Health and Welfare, 2014; SOU 2014:71). Also, one concern is that IPV services, when developed, may fail to become well-established and integrated parts of regular organisations (SOU 2015:55; cf. The Nordic Council of Ministers, 2017). Lack of resources, weak local 
political initiatives or determination and conflicting understandings of the nature of the problem are some of the suggested barriers to the development of effective social work responses to IPV (e.g., Barrett et al., 2016; Ekström, 2018; Häggblom \& Möller, 2009; SOU 2004:121, SOU 2015:55).

Given the responsibility of municipalities to provide support and services to victims of IPV, factors that may impede or increase the opportunities for successful integration of this group into local social work practice ought to be examined. The present study builds on interviews with IPV coordinators and other members of staff with a more or less formal responsibility of introducing, developing and/or handling IPV in Swedish social services. The development of IPV coordinators, who are usually responsible for exploring, initiating and developing services related to IPV, has been a widespread approach for implementing IPV services in Swedish municipalities. This position is usually mandated to instigate organisational change, such as through the introduction of new administrative routines related to the identification or investigation of IPV cases or increases in staff members' competence through training initiatives. In this article, we aim to analyse these professionals' views on organisational conditions that promote or hinder incorporation of IPV into municipal social services. The following research questions are addressed:

- Which conditions or features are stressed as important for facilitating the incorporation of IPV into social services?

- Which aspects or circumstances are considered barriers to the incorporation of IPV into social services?

- Drawing upon a theoretical framework comprised of neo-institutional theory and social movement studies and given the specific circumstances of Swedish social services and IPV, how can the processes of organisational change and resistance be understood?

\section{Background}

During the last decades, IPV has been recognised as a gender-based problem affecting women's access to equal rights, physical safety and integrity (e.g., Garcia \& Merlo, 2016; Jonassen, 2013; SOU 2004:121; Steen, 2003). For a long time, the women's shelter movement has been the main actor offering support to IPV victims and working to raise awareness of IPV, with engagement of voluntary staff as one of its core principles (Eduards, 2002).

From a feminist standpoint, violence against women is partly a cause and partly a consequence of structural inequality, which implies that the risk of violence 
affects women beyond those who are actually victimised (Hearn, 2013; Lehrner \& Allen, 2009; Wendt Höjer, 2002). By the early 2000s, it was acknowledged in both academic research and national government investigations that IPV was a prevalent experience among women in general (Lundgren, Heimer, Westerstrand, \& Kalliokoski, 2002; SOU 2004:121; Wendt Höjer, 2002). Today, however, with the expansion of both research and practice, there are multiple perspectives on IPV not only in academia but also in politics and practical social work (Mattsson, 2013; Nilsson, 2009; Steen, 2003). Further, as a central provider of IPV services, the women's shelter movement has increasingly moved towards collaboration and professional legitimacy (e.g., Wies, 2008; Barrett et al., 2016; Mehrotra, et al., 2016).

In general, Swedish municipal social service organisations consist of two main branches, one of which provides care to the elderly and disabled and one of which-so-called personal social services— provides services to (non-disabled) children and adults. By tradition, the main focuses of personal social services are provision of child welfare services, (non-medical) treatment of substance/alcohol abuse in adults and administration of social assistance benefits. Personal social service organisations also tend to be specialised in accordance with these core domains, for example, child welfare services may be performed in units that are organisationally separated from those that administer social assistance benefits (e.g., Stranz et al., 2016). Hence, there is an obvious risk that social problems such as IPV, which are not directly related to any of these core domains, fall into an organisational vacuum (cf. Ekström, 2018; Lundberg, 2018).

National regulations and recommendations regarding municipal social work practice in Sweden are issued by the National Board of Health and Welfare. The regulations regarding social work with IPV (SOSFS 2014:4) stipulate that local social services should assess the needs of IPV victims seeking assistance and offer services based on their individual needs for shelter and support. Nongovernment actors may act on assignment of the social services to carry out services to victims of IPV. Although the National Board of Health and Welfare states that all social service caseworkers should have the knowledge and skills needed to handle cases that involve IPV (SOSFS 2014:4), 'competence' and 'skills' are not clearly defined. In fact, empirical data indicate that Swedish social workers consider themselves rather ill-equipped to handle IPV cases (Lundberg \& Bergmark, 2018).

Since the late 1990s, government funding has been continuously allocated to municipalities intending to develop IPV routines or services. The first official government report on how IPV is handled in public agencies (SOU 2004:121) 
indicated that implementation of IPV support had been unsuccessful not only within the social services but also in a number of other agencies. Lack of prioritization and resource allocation as well as insufficient co-operation between agencies were some of the problems specified (SOU 2004:121). Later reports show that the professional field of IPV is generally expanding in Sweden, but considerable investments have been linked to short-term projects and, hence, have not left a lasting impression on current practical social work (SOU 2015:55). In the broader Nordic context, aspects such as a top-down implementation approach, reluctance to allocate resources and lack of commitment to IPV have been identified as factors resulting in a rather limited effect (e.g., Jonassen, 2005; Häggblom \& Möller, 2009; The Nordic Council of Ministers, 2017). There are also studies that point out the significance of political and leadership priorities at the local level, including allocation of resources, organisational support and appointment of responsibility to specific staff members (e.g., Ekström, 2018; Hjalmarson, 2015; Münger, 2015, Swedish Association of Local Authorities and Regions, 2016).

\section{Theoretical Considerations}

Neo-institutional theory has shown how organisations establish frameworks of rules and taken-for-granted practices in the form of norms, routines and beliefs through processes of institutionalisation (Powell \& DiMaggio, 1991; Scott, 2005). Within the field of locally governed social work, institutionalisation may influence, for instance, organisational structures, the distribution of resources and day-to-day routines. Incorporation of a social problem such as IPV into the practices of long-standing personal social service organisations demands some degree of change in institutionalised routines and arrangements (cf. Campbell, Baker, \& Mazurek, 1998). However, neo-institutional theory points out that established structures are difficult to change: As institutionalisation provides stability it also embeds individual actors in the ideals and norms of their surroundings (Powell \& DiMaggio, 1991; Scott, 2005). Still, change is an important part of the institutional theory of organisations, with one approach focusing on how conflicting institutional logics can enable institutional entrepreneurs or other agents of change to reform practices within a field (Scott, 2005).

While neo-institutional theories have evolved around the dilemma of structure and agency when approaching institutional change, social movement studies have drawn attention to the extra-organisational identities and values of organisational actors, focusing on aspects of power and social beliefs (McAdam \& Scott, 2005; Scully \& Segal, 2002). Scholars combining social movement 
studies with organisational theories have described activists' attempts to change organisations from the inside, either single-handedly as tempered radicals instigating organisational change while balancing between their conflicting loyalties to their professional identity and personal values (Meyerson \& Scully, 1995) or collectively organised as workplace grassroots activists (Scully \& Segal, 2002). The individual tempered radicals described by Meyerson and Scully (1995) come across as more reluctant and ambivalent change agents who draw motivation from their personal identity or political beliefs while remaining committed to their professions and organisations. Workplace grassroots activists, on the other hand, tend to collectively mobilise in opposition to injustice or oppression, drawing support from a broader social movement (Scully \& Segal, 2002). Despite their differences, both the radicals and activists are united by the fact that they bring outside interests and strategies into their workplaces, challenging their fields' institutional power structures.

When analysing the prerequisites for IPV social work, an approach that combines social movement perspectives with neo-institutional theories is particularly relevant. Men's violence against women have been brought into the public eye and national politics by a successful social movement, but general societal changes towards neoliberalism, increased individualism and professionalisation have changed the conditions in which the problem may be tackled (e.g., Barrett et al., 2016; Mehrotra et al., 2016).

In a time of increased formal municipal responsibility with regard to IPVservices, changes in the Swedish welfare state has made non-government organisations more and more taking on a role of social services providers acting on assignment of municipalities (Johansson, Arvidson, \& Johansson, 2015; cf. Lehrner \& Allen, 2009). Women's shelters still play an important part in the provision of support to victims of men's violence, but their services are increasingly regulated as IPV social work becomes a municipal obligation. This may indicate that women's shelters are shifting away from their role in a vocal social movement and towards their role as service-providing actors with professional staff. Even though this process not in any way is delimited to this issue, but rather part of a larger change (cf. Lundström \& Wijkström, 2012), professionalisation in the field of IPV demands for less identification with victims of violence than what has been distinguishing for the radical feminist movement (Wies, 2008). 


\section{Methods}

The article is based on data obtained via structured telephone interviews with staff members who formally (e.g., IPV coordinators or frontline managers; $n=54$ ) or informally (e.g., social workers who investigate IPV cases on a regular basis or are assigned to initiate organisational change regarding IPV through the development of administrative routines, although they are not given the formal title of IPV coordinators $(n=45)$. The staff members were recruited from 99 Swedish municipalities, with one interview in each municipality.

The interviews were carried out in 2014, and the municipalities were randomly drawn from three strata based on size: (1) $\leq 15.999$ inhabitants $(n=25)$, (2) 16.000-59.999 inhabitants $(n=50)$ and $(3) \geq 60.000$ inhabitants $(n=25)$. As only one municipality in strata 2 was unable to find the time for an interview, the external response rate was 99 per cent. The sampling frame consisted of all Swedish municipalities $(n=290)$, except the three largest cities (Stockholm, Gothenburg and Malmo), which are divided into city districts. As the present data is part of a larger research project that consists of both qualitative and quantitative data sets (for further studies conducted as part of this project, see Lundberg, 2017; Lundberg \& Bergmark, 2018), such divisions into cities districts renders it impossible to gather information that is valid for the municipality as a whole.

Nearly all the respondents (97 of 99) were women, and the interviews were conducted with the support of an interview guide consisting of questions with set responses as well as open-ended questions. The guide covered a wide range of aspects related to the organisational prerequisites for municipal work with IPV (e.g., formal/informal routines for intake and processing IPV cases; collaboration with actors within/outside of the personal social service organisation; provision of services to IPV victims, perpetrators and children that have experienced violence). In this article, we examine responses to three questions:

(1) What circumstances do you consider to facilitate or to obstruct the development of IPV work in your organisation? (open-ended responses)

(2) If you were asked to reorganise your workplace in order to enhance its ability to handle IPV cases, what type of organisation would you visualise? (open-ended responses)

(3) What is your opinion about the current level of knowledge concerning IPV within your organisation? (set responses-a=high, b=fairly high, $\mathrm{c}=$ uneven, $\mathrm{d}=$ fairly low, e=low-followed by open-ended questions intended to clarify and deepen the responses) 
We also included remarks or arguments related to the aim of this article that arose in other parts of the interviews. The interviews were not recorded, but careful notes were taken and longer responses were read back for verification. Each interview lasted for approximately 45-60 minutes.

The data were analysed by a combination of directed and conventional qualitative content analyses (cf. Hsieh \& Shannon, 2005). On the one hand, the analysis was guided by the issue focused upon in this article: The incorporation of a 'new' professional field into a pre-existing organisation. This, in turn, was based on a theoretical framework that combines perspectives from social movement studies with institutional theory. On the other hand, as the body of knowledge on the organisational prerequisites for municipality-based work with IPV is considered meagre, parts of the analysis were guided by the data rather than the theoretical framework used for the article.

Initially, all open-ended responses and clarifying remarks were read and assigned to one of eight more or less pre-defined categories or to a general, non-defined category that emerged while examining the data. In the next step, points in common between (shared by) categories were identified and the data were reorganised into three final themes: (1) a matter of personal commitment, (2) developing expertise and (3) too personal and too political. Under the first of these themes we address the facts that practical work with IPV seems to largely depend on individuals' commitment to the task and attention to IPV and skills related to this area appear to be a matter of choice. Under the second theme we present results that are centred on possibilities or hopes of increasing professionalism in the field of municipal work with IPV. Tension concerning the issue of IPV itself is related to the third theme, where aspects of commitment as well as resistance are brought forward. To increase transparency and give a more vivid presentation of data, we provide excerpts from the interviews in this article. However, as the interviews were not recorded, all quotes are derived from the notes taken during interviews. This implies that there may be some limitations with regard to details in phrasing.

Other methodological limitations of the study should be stressed. First, as pointed out, the interviews were carried out in a randomly selected sample of Swedish municipalities $(n=99)$. The municipalities varied with regard to factors such as population size, sociodemographic conditions and geographical location, enabling us to cover a greater part of the country and thereby a large variety of the organisational prerequisites for practical work with IPV, but excluded the three largest cities in Sweden. It is possible that interviews with relevant staff in these cities would have added perspectives on factors that might promote or hinder the incorporation of IPV into pre-established personal 
social service organisations. Second, since we focus on personal social services, significant parts of Swedish social services are excluded. Hence, even though our results may be partially applicable to other aspects of social service organisations, there is an obvious need for further research on how the establishment of IPV support and services can include the diverse needs of victims of IPV in the social services context as a whole.

\section{Findings}

\section{A Matter of Personal Commitment}

A Personal interest in and commitment to IPV was a recurrent theme in the interviews that was related to successful organisational adjustments, development of expertise and varying levels of IPV proficiency among frontline social workers. Regarding factors that promote work with IPV, respondents spoke of devoted individuals who pushed work forward. In fact, commitment and devotion were pointed out at various levels of the municipal hierarchy. In some cases, the respondents highlighted specific staff members (or themselves), and in other cases, they referred to managers or politicians. Regardless of the leve at which these actors were positioned, they seemed to play a significant role in raising awareness or upholding IPV work in the municipalities.

It is hard to make the politicians understand that IPV is something that has to be prioritised. But I have a manager with a passionate interest; it is necessary with someone who pushes the work forward, who carries the torch. (Front Line Manager, Municipality 64)

The importance of politically prioritising IPV was often mentioned by the respondents. Those striving to achieve greater prioritisation were frequently referred to using terms that indicate devotion and dedication. It was implied that people working to promote and develop the field of IPV are spurred by an interest beyond what is expected of them.

The work has been pushed forward partly through pressure from the National Board of Health and Welfare and partly by the two of us, who are dedicated to this. We have been given carte blanche by the manager and thanks to our colleagues, we have been able to continue our education and draw up routines, etc. (Social Worker, Municipality 97)

In some cases, devotion to IPV was referred to as a secondary activity or a line of work performed outside of regular duties that, as in the quote above, was only made possible by support from colleagues. At times, it appeared to be carried out almost as an individual mission, independent of organisational support. 
In addition to being referred to as a condition that promotes incorporation of services and routines into organisations, commitment was described as a grounds for IPV skill and competence among caseworkers in general. Acquiring knowledge about how to handle cases involving violence was often related to the level of social workers' individual commitment.

The level of skills is rather low [...] I think it has to do with personal commitment. Those who take an interest [in IPV] have acquired skills. We have relatively few [IPV] cases since people don't ask about violence. (Front Line Manager, Municipality 9)

Describing IPV skills as dependent on individual commitment implies that such skills are not expected of social workers. An individual commitment to the issue of IPV was associated rather to personal preferences than to professional responsibilities, making IPV seemingly an issue possible not to attend to. As a condition promoting incorporation of practical work with IPV, dependence on individual commitment seems like a source of variation between both units and municipalities.

The level of knowledge is uneven between different units [... and is] tied to individual staff members. Some examples are scary; psychological violence is considered as nothing, but physical violence, that is real violence. (IPV Coordinator, Municipality 41)

\section{Developing Expertise}

A great majority of the respondents emphasised the need to develop or expand IPV expertise within personal social services. In most municipalities, some specialisation had already been developed, and it was apparent that the respondents based their desire for further development on what already existed. The respondents in smaller municipalities mainly hoped for time explicitly allocated to IPV, as opposed to trying to fit work with cases of violence in between other tasks. In the larger municipalities, many respondents expressed a wish to establish separate IPV units or teams. A lack of IPV-specific resources was frequently mentioned in relation to the significance of political and managerial prioritisation of IPV as well as the context of legitimacy.

\footnotetext{
Work done with violence is much about how high priority the issue is given in the council and with the managers. Some slow it down, others are committed. I would wish the municipality to raise the issue in all sectors. It does not have real legitimacy yet, far from it, but it is getting better. It is obvious that violence is not yet an area in its own right. (IPV Coordinator, Municipality 31)
}

Respondents argued for the development of specific IPV expertise, mainly by pointing to a likely increase in the quality of case work and support. They related their thoughts to what they perceived to be randomness in the quality of IPV 
investigation due to varying skills and routines between organisational units and individual social workers. IPV being handled by units mainly focusing on other social problems was frequently stated as a significant problem. In order to increase the quality of practical work with IPV, respondents called for IPV to be viewed a specific social problem that requires specific competence. But the demand for specialised competence implies not only proficiency in casework but also a certain amount of pressure on organisations to maintain focus on IPV.

Specialisation is needed to keep focus on the violence; in order to perform risk assessments and investigations of high quality, one has to work a lot with violence. It is easy to lose focus otherwise. (Front Line Manager, Municipality 43)

The matter of IPV being left out from both organisational agendas and practical casework was frequently underlined. With IPV not being a professional field of its own, respondents spoke of continuous efforts to keep the issue from getting neglected.

You can never relax; you always have to be there and point out violenceit keeps disappearing, as in new treatment methods. Every other case includes violence, especially in child and family cases. All the time, one needs to uphold the issue of violence. (IPV Coordinator, Municipality 22)

One suggested solution to resource-related problems was development of IPV specialisation within other areas, particularly child welfare services, or relocation of staff from other units to teams or groups working with IPV. The respondents argued that with IPV specialised case workers within child welfare services, aspects of violence would not risk getting lost when parents and children are investigated. This approach, however, does not necessarily imply a desire to transfer resources; it may be understood as a request to include IPV in the work performed within other areas of competence. This line of reasoning suggests that many of the concerned clients are already present within the organisation, but their experiences of violence are not properly or sufficiently addressed.

Many respondents referred to general financial hardship within personal social services and pointed out that practical work with IPV is characterised by loss of expertise due to cutbacks and staff turnover. Dependence on temporary project funding was a recurrent problem and there are indications that the process of incorporating practical work with IPV into PSS may in some municipalities be moving in reverse. In a few interviews there were reports of organisational measures being taken to circumscribe demands, for example by not advertising IPV services when there is a waiting list. Other respondents worried about the financial consequences of increased competence and routines.

The social services are always under financial pressure. If everyone is to be screened for violence, the number of IPV cases will increase. Will 
resources be enough then? I have heard of other municipalities that quit asking since there were too many cases. (IPV Coordinator, Municipality 32)

\section{Too Political and Too Personal}

While there were reports of organisational progression on the one hand and slow-changing organisations on the other, some of the respondents had faced more open resistance to incorporating IPV into personal social services. Mainly, they related this opposition to the issue itself; they described the gendered aspect of IPV as challenging to underline, as it touches upon a general and societal lack of gender equality. As pointed out by one respondent, equality as an ideal might become a barrier when that ideal grows into a normative standard and even a general view on the state of affairs.

The issue of men's violence against women is not taken seriously; it is controversial to point out the gendered aspect, since we are supposed to have gender equality in Sweden. (IPV Coordinator, Municipality 41)

When IPV is related to inequality and patriarchal structures, the problem takes on a more political dimension, as does the (lack of) resources and prioritisation of incorporating social work with IPV.

\footnotetext{
We still live in a patriarchal society. This is still a women's issue. [...] We have faced a lot of resistance. Violence is so tricky. It is hard to investigate, time-consuming and people get annoyed with the women for them not being able to protect their children and all that. (Social Worker, Municipality 21)
}

When IPV was put into the context of gender inequality, the similarities between professional work with IPV and the women's shelters movement, which may be viewed as a feminist activist movement, were described as a possible source of ideological tension.

There are those who think people should not listen too much to [IPV specialists]; they say they are like those women's shelter activists. (IPV Coordinator, Municipality 80)

One basic principle of the women's shelter movement is drawing attention to the high prevalence of IPV as well as the diverse group of women experiencing violence. As IPV is considered part of the female experience of oppression, it has been stressed that victims of IPV do not differ from women in general. This view was observed in some parts of the interviews, when respondents related the difficulty of working with IPV to personal experiences among staff members and personal attitudes towards gender and equality.

I have never experienced such resistance against any other issue. [...] It might be about personal experiences, about women and gender, about 
their own lives. There needs to be more done for staff members who have been abused. (Social Worker, Municipality 21)

The suggestion that staff members have personal experiences with IPV is supported by the prevalence of the problem, and it may be related to the framing of men's violence against women as a problem that affects women in general, disregarding social class, age and ethnicity. Apart from the matter of personal experience, IPV was depicted as an intimate and generally upsetting problem, raising fear and apprehension among staff members and setting it apart from other social problems.

Violence is difficult, scary and personal. There is a difference between education and skill that involves personal ability. (IPV Coordinator, Municipality 85)

The efforts of the feminist movement to raise public awareness of violence against women may be considered a success given the national political attention this issue has received. However, this notion may be disputed due to respondents' emphasis on the significance of personal commitment in the process of incorporating IPV into social work. Social workers handle a large range of social problems, yet IPV was described as an issue relying upon personal commitment and devotion and evoking personal concern, fear and resistance.

\section{Discussion and Conclusion}

The aim of this article has been to analyse conditions that promote or hinder local development of social work with IPV by examining the experiences of those working to integrate IPV into Swedish personal social services. Our results show that the respondents largely associated successful incorporation of IPV with the dedication of individual actors within their organisations. While carrying out their work, these staff members were described as being devoted to IPV beyond their professional obligations. As individual social workers taking a special interest in the area of IPV appeared as an important feature of organisational change, skill with regard to IPV came across as 'a matter of choice' rather than a natural part of professional competence.

The focus on personal commitment as a fundamental factor for organisational change within social services parallels the original idea of a social movement. However, change efforts associated with social movements are typically mobilized collectively, for instance in the form of workplace grassroots activism (cf. Scully \& Segal, 2003). As organisational change in this context seems to be initiated and led by individuals rather than a collective, the results indicate that the respondents-or those mentioned by the respondents-bear more 
resemblance to the tempered radicals described by Meyerson and Scully (1995) than to grassroots activists. When questioning and challenging institutionalised practices from within organisations, these actors aim to transform what is considered as personal commitment into professional expertise.

The potential success of individual efforts depends on the level of organisational support one receives (cf. Ekström, 2018). In order to gain access to support, one needs to adapt to the norms, routines and beliefs that characterise one's organisation (cf. Powell \& DiMaggio, 1991; Scott, 2005). In social services, this implies greater emphasis on professionalism and specialisation, while a more radical, macro-oriented approach towards IPV could be less likely to achieve legitimacy. This strive for increased legitimacy is mirrored by a similar process within the contemporary women's shelter movement in which the function of service provider call for deemphasised activism in favour of professionalism (cf. Mehrotra et al., 2016; Wies, 2008).

Instigating organisational change may stir up opposition as making room for a new area of expertise can put the resources allocated to other areas at risk. Professional legitimacy is one of the more significant objectives described in the interviews, and the respondents frequently request both organisational and professional specialisation regarding IPV. Arguments for this revolve around increasing the overall quality of the work performed, creating a permanent space in the organisation for IPV and developing expertise in that area. Specialisation being an evident trend and possibly becoming an institutionalised way of handling recognised social problems within the Swedish personal social service (Stranz et al., 2016), this request may indicate an influence of the internal logics of social services on the incorporation process of IPV. Still, with limited municipal resources and organisational inertia, this request is likely to meet resistance.

Integrating a new area of work may also challenge long-standing organisational routines and beliefs. Swedish social work rests on family support values, emphasising cooperation with and between parents, and preventive rather than protective services (Leviner, 2014). IPV, on the other hand, is an area that highlights power, conflict and opposing interests within families. Consequently, when staff try to integrate IPV into social work practice, they may question what appears as core values of Swedish social work.

As the high prevalence of IPV is an obvious argument when trying to instigate organisational change, pointing out the gendered aspects of the problem in a social service context may be interpreted as taking a political standpoint and, consequently, may be a barrier to integration of the issue of violence into social 
services. The Swedish welfare state has been suggested to rest on principles of collectivism and accordance in reducing social problems and as being less apt to recognise social divisions and conflicts due to race, gender and disability (Pringle, 2010). Correspondingly, as IPV is being incorporated into the personal social service, the gender-based aspects have been somewhat defused. Actors such as the National Board of Health and Welfare use gender-neutral language in everything from regulations and guidelines to standardised measures and IPV assessment tools (Stranz, Vogel, \& Wiklund, 2015), as do numerous treatment centres and personal social service units focusing on IPV (Mattsson, 2013).

With the issue of IPV moving between the contexts of social movement on the one hand and the municipal social services on the other, in a time when the boundaries of these fields tend to overlap, different institutional logics may influence and transform the practices of both arenas. One obvious clash of rationalities is the strong reliance on personal devotion of the social workers who are struggling for professional legitimacy in the bureaucratic context of personal social services. Providing support to victims of IPV is a mandatory part of municipal social work. Yet, according to the present study, what is in fact an organisational obligation tends to rely on the commitment of individual social workers, putting them in an apparently difficult position. On the other hand, while IPV social work may well challenge institutionalised practises within the personal social service, change may go both ways with the issue of IPV being reframed to fit into the established framework of a social service context.

When professionalism and legitimacy become an ideal within both nongovernment organisations and the social services, the boundaries of social movement become more difficult to distinguish. In order to better understand how IPV is transforming into a field involving both municipal social services and the women's shelter movement there is a need for further studies of how strategies and perceptions have changed over time. As non-governmental organisations still play a significant part in the field of IPV in other Nordic countries and Anglo-Saxon countries, it would be beneficial to examine this topic from a comparative perspective.

\section{References}

Barrett, B. J., Almanssori, S., Kwan, D. L., \& Waddick, E. (2016). Feminism within domestic violence coalitions: A quantitative content analysis. Affilia, 31(3), 359371. https://doi.org/10.1177/0886109915578729

Campbell, R., Baker, C. K., \& Mazurek, T. L. (1998). Remaining radical? Organizational predictors of rape crisis centers' social change initiatives. American Journal of 
Community Psychology, 26(3), 457-483.

https://doi.org/10.1023/A:1022115322289

Eduards, M. (2002). Förbjuden handling: om kvinnors organisering och feministisk teori [Forbidden action: On women's organisation and feminist theory]. Malmö: Liber.

Ekström, V. (2018). Carriers of the troublesome violence-the social services' support for female victims of domestic violence. European Journal of Social Work, 21(1), 61-73. https://doi.org/10.1080/13691457.2016.1255930

European Union Agency For Fundamental Rights (2014). Violence against women: An EU-wide survey. Luxembourg: Publications Office of the European Union.

Garcia, E., \& Merlo, J. (2016). Intimate partner violence against women and the Nordic paradox. Social Science \& Medicine, 157, 27-30. https://doi.org/10.1016/j.socscimed.2016.03.040

Hearn, J. (2013). The sociological significance of domestic violence: Tensions, paradoxes and implications. Current Sociology, 61(2), 152-170. https://doi.org/10.1177/0011392112456503

Hjalmarson, I. (2015). Att arbeta med våld i nära relationer. En beskrivning av och erfarenheter från projektet Freda inom omsorgen om äldre och funktionsnedsatta [Practical work with IPV. Using Freda in elderly and disability care]. Stockholm: Region Gotland/Äldrecentrum.

Hsieh, H. F., \& Shannon, S. E. (2005). Three approaches to qualitative content analysis. Qualitative Health Research, 15(9), 1277-1288. https://doi.org/10.1177/1049732305276687

Häggblom, A., \& Möller, A. (2009). Implementation of a government policy programme on Operation Kvinnofrid. Nursing Inquiry, 16(1), 43-52. https://doi.org/10.1111/j.1440-1800.2009.00439.x

Johansson, H., Arvidson, M., \& Johansson, S. (2015). Welfare mix as a contested terrain: Political positions on government-non-profit relations at national and local levels in a social democratic welfare state. Voluntas, 26(5), 1601-1619. https://doi.org/10.1007/s11266-015-9580-4

Jonassen, W. (2005). Marching on the spot? Dealing with violence against women in Norway. In M. Eriksson, M. Hester, S. Keskinen, \& K. Pringle (Eds.), Tackling men's violence in families: Nordic issues and dilemmas, 83-100 Bristol: Policy Press. https://doi.org/10.2307/j.ctt9qgq9j.11

Jonassen, W. (2013). Fra kvinnemishandling til vold i nære relasjoner: Regjeringens handlingsplaner mot vold [The government's action plans against violence]. Tidsskrift for kjønnsforskning, 37(1), 46-62.

Lehrner, A., \& Allen, N. E. (2009). Still a movement after all these years? Current tensions in the domestic violence movement. Violence Against Women, 15(6), 656-677. https://doi.org/10.1177/1077801209332185

Leviner, P. (2014). Child protection under Swedish law - legal duality and uncertainty. European Journal of Social Work, 17(2), 206-220. https://doi.org/10.1080/13691457.2013.791249

Lundberg, L. (2018). A new area of expertise? Incorporating social work with intimate partner violence into Swedish social services organizations. Nordic Social Work Research, 8(2), 171-184. https://doi.org/10.1080/2156857X.2017.1343744

Lundberg, L., \& Bergmark, Å. (2018). Self-perceived competence and willingness to ask about intimate partner violence among Swedish social workers. European Journal of Social Work, 1-12. https://doi.org/10.1080/13691457.2018.1540970 
Lundgren, E., Heimer, G., Westerstrand, J., \& Kalliokoski, A. (2002). Captured queen: Men's violence against women in "equal" Sweden: A prevalence study. Umeå: Brottsoffermyndigheten.

Mattsson, T. (2013). Motstånd och neutralisering. Kön, makt och professionalitet i arbetet med våld i nära relationer [Resistance and neutralisation. Gender, power and professionalism in work with intimate partner violence]. Socialvetenskaplig tidskrift, 20(3-4), 150-167.

McAdam, D., \& Scott, W.R. (2005). Organizations and movements. In G. F. Davis, D. McAdam, W. R. Scott, \& M. N. Zald (Eds.), Social movements and organization theory, 4-40. Cambridge, UK: Cambridge University Press. https://doi.org/10.1017/CBO9780511791000.003

Mehrotra, G. R., Kimball, E., \& Wahab, S. (2016). The braid that binds us: The impact of neoliberalism, criminalization, and professionalization on domestic violence work. Affilia, 31(2), 153-163. https://doi.org/10.1177/0886109916643871

Meyerson, D., \& Scully, M. (1995). Tempered radicalism and the politics of ambivalence and change. Organization Science, 6(5), 585-600. https://doi.org/10.1287/orsc.6.5.585

Münger, A. C. (2015). En brukarundersökning om sex stockholmskommuners arbete mot våld i nära relationer [Work against intimate partner violence. A client inquiry]. Stockholm: FoU-Nordväst.

National Board of Health and Welfare. (2014). Öppna jämförelser 2014. Stöd till brottsoffer. Nationella resultat, metod och indikatorer [Open comparisons 2014 Assistance to crime victims]. Stockholm: National Board of Health and Welfare.

Nilsson, G. (2009). Könsmakt eller häxjakt? Antagonistiska föreställningar om mäns våld mot kvinnor [Gender power or witch hunt? Antagonist beliefs about men's violence against women]. Lund: Lund University.

The Nordic Council of Ministers. (2005). Gender \& violence. A Nordic research programme. Copenhagen: The Nordic Council of Ministers.

The Nordic Council of Ministers. (2017). Nordic countries overview of work with perpetrators of intimate partner violence. Copenhagen: The Nordic Council of Ministers.

Powell, W. W., \& DiMaggio, P. J. (1991). The new institutionalism in organizational analysis. Chicago, IL: University of Chicago Press. https://doi.org/10.7208/chicago/9780226185941.001.0001

Pringle, K. (2010). Swedish welfare responses to ethnicity: The case of children and their families. European Journal of Social Work, 13(1), 19-34. https://doi.org/10.1080/13691450903135659

Scully, M., \& Segal, A. (2002). Passion with an umbrella: Grassroots activists in the workplace. In M. Lounsbury, M. J. Ventresca (Ed.), Social structure and organizations revisited (125-168). Bingley, UK: Emerald Group Publishing Limited. https://doi.org/10.1016/S0733-558X(02)19004-5

Scott, W. R. (2005). Institutions and organizations. Thousand Oaks, CA: SAGE Publications.

SOSFS. (2014:4). Våld i nära relationer [Intimate partner violence]. Stockholm: National Board of Health and Welfare.

SOU. (2004:121). Slag i luften: en utredning om myndigheter, mansvald och makt [Paper tiger: An investigation on authorities, male violence and power]. Stockholm: Socialdepartementet. 
SOU. (2014:71). Ett jämställt samhälle fritt från våld. Utvärdering av regeringens satsningar 2010-2014 [An equal society free from violence. Government initiatives 2010-2014.]. Stockholm: Socialdepartementet.

SOU. (2015:55). Nationell strategi mot mäns våld mot kvinnor och hedersrelaterat våld och förtryck [National strategy against men's violence against women and honour-related violence]. Stockholm: Socialdepartementet.

Stranz, H., Vogel, M. A., \& Wiklund, S. (2015). Utvärdering av FREDAbedömningsmetoder $i$ arbetet med våldsutsatta [Evaluation of the FREDA assessment]. Stockholm: Stockholm University.

Stranz, H., Wiklund, S., \& Karlsson, P. (2016). People processing in Swedish personal social services. On the individuals, their predicaments and the outcomes of organisational screening. Nordic Social Work Research, 6(3), 174-187. https://doi.org/10.1080/2156857X.2015.1134630

Steen, A-L. (2003). Mäns våld mot kvinnor - ett diskursivt slagfält: reflektioner kring kunskapsläget [Men's violence against women - a discursive battlefield: reflections on the state of knowledge]. Gothenburg: University of Gothenburg.

Wendt Höjer, M. (2002). Rädslans politik: Våld och sexualitet i den svenska demokratin [The politics of fear: Violence and sexuality in the Swedish democracy]. Stockholm: Liber.

Wies, J. R. (2008). Professionalizing human services: A case of domestic violence shelter advocates. Human Organization, 67(2), 221-233. https://doi.org/10.17730/humo.67.2.143m2v54221711/3 